\title{
Pengaruh Asimetri Informasi Pada Senjangan Anggaran Dengan Kejelasan Sasaran Anggaran dan Komitmen Organisasi Sebagai Pemoderasi
}

\author{
Ni Made Kusuma Ayuni ${ }^{1}$ \\ Ni Made Adi Erawati ${ }^{2}$
}

\author{
${ }^{1}$ Fakultas Ekonomi dan Bisnis Universitas Udayana (Unud), Bali, Indonesia \\ e-mail: ayuniayyu @ gmail.com / telp: +6285792726444 \\ ${ }^{2}$ Fakultas Ekonomi dan Bisnis Universitas Udayana (Unud), Bali, Indonesia
}

\begin{abstract}
ABSTRAK
Anggaran merupakan rencana keuangan masa mendatang yang mencakup harapan manajemen terhadap pendapatan, biaya dan transaksi keuangan lain dalam masa satu tahun. Anggaran organisasi publik mencakup rencana-rencana tentang berapa biaya atas rencana yang dibuat dan berapa banyak serta bagaimana cara memperoleh uang untuk mendanai rencana tersebut. Senjangan anggaran adalah suatu kesenjangan yang dilakukan oleh manajer atau bawahan dalam berpartisipasi untuk menyusun anggaran dengan memberikan estimasi anggaran yang tidak sesuai dengan keadaan sesungguhnya. Penelitian ini bertujuan untuk mengetahui pengaruh asimetri informasi pada senjangan anggaran, dengan kejelasan sasaran anggaran dan komitmen organisasi sebagai variabel pemoderasi. Penelitian ini dilaksanakan pada Satuan Kerja Perangkat Daerah (SKPD) yang berupa Dinas di Kabupaten Tabanan. Populasi dalam penelitian ini sebanyak 19 dinas dan jumlah sampel yang diteliti yaitu 57 orang. Teknik penentuan sampel dalam penelitian ini adalah dengan metode sampel jenuh yaitu semua populasi dapat dijadikan sampel penelitian. Responden sampel dalam penelitian ini adalah Kepala Dinas, Kepala Sub. Bagian Umum dan Perencanaan, serta Kepala Sub. Bagian Keuangan. Pengumpulan data dilakukan melalui penyebaran kuesioner. Teknik analisis data yang digunakan adalah analisis regresi linier sederhana dan moderate regression analysis. Berdasarkan hasil analisis disimpulkan bahwa asimetri infromasi berpengaruh positif pada senjangan anggaran, kejelasan sasaran anggaran berpengaruh negatif (memperlemah) hubungan asimetri informasi pada senjangan anggaran, dan komitmen organisasi tidak memoderasi hubungan asimetri informasi pada senjangan anggaran Dinas Pemerintah Kabupaten Tabanan.
\end{abstract}

Kata kunci: asimetri informasi, senjangan anggaran, kejelasan sasaran anggaran, komitmen organisasi.

\begin{abstract}
Budget is a future financial plan that covers management's expectations of revenue, expenses and other financial transactions within a year. The budget of a public organization includes plans on how much the plan will cost and how much money and how to fund money to realize the plan. Budgetary slack is a gap by managers or subordinates in participating to budget by giving budget estimates that do not fit the actual situation. This study aims to determine the effect of information asymmetry on budgetary slack, with clarity of budget target and organizational commitment as a moderating variable. This research was conducted at the regional device work unit of departement in Tabanan Regency. The population in this study are 19 departement and the number of samples studied were 57 people. The technique of determining the sample used in this study is saturated samples method that all the population can be used as research samples. Respondent of sample in this research is head of department, head of sub. general and planning section, and head of sub. financial department. Data collection was done through questionnaires. Data analysis techniques used are simple linear regression analysis and moderated regression analysis. Based on the results it is concluded that the information asymmetry has a positive effect on budgetary slack, the clarity of the budget target has negative effect (weakening) the relationship of information asymmetry on budgetary slack,
\end{abstract}


Ni Made Kusuma Ayuni dan Ni Made Adi Erawati. Pengaruh ...

and organizational commitment does not moderate the relationship of information asymmetry at budgetary slack of Tabanan District Government.

Keywords: information asymmetry, budgetary slack, clarity of budget target, organizational commitment.

\section{PENDAHULUAN}

Anggaran merupakan rencana keuangan masa mendatang yang mencakup harapan manajemen terhadap pendapatan, biaya dan transaksi keuangan lain dalam masa satu tahun. Anggaran organisasi publik mencakup rencana-rencana tentang berapa biaya atas rencana yang dibuat dan berapa banyak serta bagaimana cara memperoleh uang untuk mendanai rencana tersebut. Anggaran merupakan salah satu pilar dalam perencanaan pembangunan bagi pemerintah. Senjangan anggaran dapat terjadi ketika orang-orang yang terlibat dalam menciptakan anggaran sengaja melebih-lebihkan jumlah biaya selama periode anggaran. Selain itu adanya senjangan anggaran berarti, tidak tercapainya tujuan kinerja yang baik dalam pemerintahan, sehingga pemerintah akan tampak gagal dalam menjalankan prinsip anggaran dalam anggaran sektor publik.

Senjangan anggaran dapat terjadi dalam kondisi asimetri informasi karena dengan adanya informasi yang bias antara atasan dengan bawahan mendorong bawahan atau pelaksana anggaran membuat senjangan anggaran. Secara teoritis, asimetri informasi dapat dikurangi dengan memperkuat monitoring dan meningkatkan kualitas pengungkapan (Suartana, 2010). Penelitian mengenai pengaruh asimetri informasi dengan senjangan anggaran telah banyak dilakukan dengan hasil yang berbeda-beda. Dunk (1993), Young (1985), Latif (2013), Sujana (2010), dan De Faria (2013) menyatakan bahwa asimetri informasi berpengaruh terhadap adanya senjangan anggaran. Lau dan Eggleton (2003) 
menyatakan bahwa interaksi asimetri informasi merupakan faktor utama penyebab timbulnya senjangan anggaran. Sedangkan penelitian yang dilakukan oleh Roudhiah (2014) dan Pello (2014) menyatakan bahwa asimetri informasi berpengaruh negatif terhadap senjangan anggaran.

Penelitian-penelitian tersebut memperlihatkan masih terdapat ketidakkonsistenan dari hasil penelitian sebelumnya. Maka peneliti melakukan penelitian kembali mengenai pengaruh asimetri informasi dengan senjangan anggaran. Peneliti juga menggunakan variabel pemoderasi yang mungkin mempengaruhi senjangan anggaran, yaitu kejelasan sasaran anggaran dan komitmen organisasi. Anggaran juga merupakan alat bantu manajemen dalam mengalokasikan keterbatasan sumber daya alam dan sumber daya dana yang dimiliki organisasi untuk mencapai tujuan. Salah satu karakteristik anggaran adalah kejelasan sasaran anggaran.

Kejelasan sasaran anggaran juga berimplikasi pada aparatur pemerintah untuk menyusun sasaran yang ingin dicapai instansi pemerintah, sehingga aparatur pemerintah memiliki informasi yang cukup untuk memprediksi masa depan secara cepat. Kemampuan inilah yang nantinya akan mengurangi terjadinya senjangan anggaran. Sejalan dengan penelitian yang dilakukan oleh Stevens (2000) yang menyebutkan bahwa senjangan anggaran berhubungan dengan empat kondisi yang salah satunya adalah adanya sasaran anggaran yang bertentangan antara atasan dan bawahan. Sasaran yang ditetapkan secara jelas akan memudahkan bawahan untuk mencapainya, sehingga bawahan akan memberikan kinerja yang terbaik dan ini mencegah munculnya perilaku disfungsional yang 
Ni Made Kusuma Ayuni dan Ni Made Adi Erawati. Pengaruh ...

akan merugikan organisasi, salah satu diantaranya adalah senjangan anggaran. Adanya sasaran anggaran yang jelas akan memudahkan individu untuk menyusun target-target anggarannya. Selanjutnya, target anggaran yang disusun akan sesuai dengan anggaran yang ingin dicapai organisasi. Hal ini berimplikasi pada penurunan senjangan anggaran (budgetary slack).

Selain asimetri informasi dan kejelasan sasaran anggaran, terdapat pula faktor lain yang menyebabkan terjadinya senjangan anggaran, salah satunya adalah komitmen organisasi. Komitmen organisasi merupakan keyakinan dan dukungan yang kuat terhadap nilai dan sasaran yang ingin dicapai organisasi dan sejauh mana indivdu mengenal dan terikat pada organisasinya (Zurnali, 2010). Apabila individu memiliki komitmen yang tinggi akan lebih mengutamakan kepentingan organisasinya atau kelompoknya. Penelitian Amirrudin dan Auzair (2014) menemukan adanya pengaruh yang negatif dan signifikan interaksi antara komitmen organisasi dimensi emotions attachment dengan partisipasi anggaran terhadap senjangan anggaran. Hal ini berarti semakin besar komitmen organisasi, akan menyebabkan semakin menurun keinginan individu yang terlibat di dalam penyusunan anggaran untuk melakukan senjangan anggaran. Banyak penelitian sebelumnya meneliti senjangan anggaran di rumah sakit, hotel berbintang, PT (Perseroan Terbatas) dan lainnya. Namun penelitian ini akan meneliti organisasi pemerintahan yaitu SKPD berupa Dinas Pemerintah Kabupaten Tabanan karena data dalam laporan realisasi anggaran selalu menunjukan senjangan anggaran. 
ISSN: 2302-8556

E-Jurnal Akuntansi Universitas Udayana

Vol.22.1. Januari (2018): 492-520

Tabel 1.

Realisasi Pendapatan Kabupaten Tabanan Tahun Anggaran 2011-2015

\begin{tabular}{ccccc}
\hline Tahun & $\begin{array}{c}\text { Anggaran } \\
\text { Pendapatan }\end{array}$ & $\begin{array}{c}\text { Realisasi } \\
\text { Pendapatan }\end{array}$ & Selisih & (\%) \\
\hline 2011 & $870.487 .009 .003,81$ & $886.307 .833 .591,26$ & $15.820 .824 .587,45$ & $101,8 \%$ \\
2012 & $1.055 .763 .949 .897,51$ & $1.056 .319 .329 .214,79$ & $555.379 .317,28$ & $100,1 \%$ \\
2013 & $1.214 .809 .607 .696,63$ & $1.253 .026 .818 .659,65$ & $38.217 .210 .963,02$ & $103,1 \%$ \\
2014 & $1.328 .610 .781 .308,50$ & $1.367 .063 .683 .393,04$ & $38.452 .902 .084,54$ & $102,9 \%$ \\
2015 & $1.442 .947 .436 .391,73$ & $1.516 .483 .687 .766,54$ & $73.536 .251 .374,81$ & $105,10 \%$ \\
\hline
\end{tabular}

Sumber: Bappeda Kabupaten Tabanan, 2016 (data diolah)

Berdasarkan Tabel 1. memperlihatkan terjadinya senjangan anggaran dalam

APBD Kabupaten Tabanan karena realisasi selalu lebih tinggi daripada anggaran pendapatan daerah yang ditetapkan. Pada tahun 2015 terdapat jumlah selisih yang cukup besar yaitu $73.536 .251 .374,81$ atau $105,10 \%$, dilihat dari data tersebut dapat diketahui estimasi anggaran tidak memperhatikan realisasi anggaran tahun sebelumnya. Hal ini terlihat dari rencana yang telah ditetapkan bahwa realisasi anggaran yang dialokasikan cenderung mengalami peningkatan dan secara presentasi realisasinya cenderung tidak stabil.

Tabel 2.

Realisasi Anggaran Belanja Daerah Kabupaten Tabanan Tahun Anggaran 2011-2015

\begin{tabular}{ccccc}
\hline Tahun & $\begin{array}{c}\text { Anggaran Belanja } \\
\text { Daerah }\end{array}$ & $\begin{array}{c}\text { Realisasi Belanja } \\
\text { Daerah }\end{array}$ & Selisih & (\%) \\
\hline 2011 & $920.541 .111 .162,07$ & $882.459 .134 .393,14$ & $66.271 .730 .769,08$ & $95,86 \%$ \\
2012 & $1.108 .188 .715 .959,77$ & $1.041 .916 .985 .190,69$ & $555.379 .317,28$ & $94,02 \%$ \\
2013 & $1.252 .899 .104 .448,74$ & $1.198 .702 .306 .735,59$ & $54.196 .797 .713,15$ & $95,67 \%$ \\
2014 & $1.415 .634 .479 .690,55$ & $1.325 .575 .026 .481,23$ & $90.059 .453 .209,32$ & $93,64 \%$ \\
2015 & $1.467 .667 .436 .391,73$ & $1.507 .013 .032 .576,50$ & $73.536 .251 .374,81$ & $102,68 \%$ \\
\hline Sumber: Bappeda Kabupaten Tabanan, 2016 (data diolah) & &
\end{tabular}

Berdasarkan Tabel 2. memperlihatkan anggaran realisasi belanja lebih kecil daripada anggaran yang ditetapkan. Laporan realisasi anggaran belanja tahun 2011-2014 menunjukkan bahwa jumlah anggaran yang ditetapkan kurang dari 100\% dan tahun 2015 lebih dari 100\% terealisasikan. Dilihat dari data tersebut 
Ni Made Kusuma Ayuni dan Ni Made Adi Erawati. Pengaruh ...

anggaran diestimasi dengan sengaja agar jumlah yang tertera lebih tinggi atau bahkan lebih kurang dari yang seharusnya, sehingga dapat menimbulkan senjangan anggaran. Hal ini menunjukan bahwa belum seluruhnya realisasi anggaran dapat terserap oleh alokasi belanja rutin maupun belanja pembangunan yang mengakibatkan sisa lebih perhitungan pada setiap tahun anggaran.

Pada konteks pemerintahan daerah, aparat yang merasa sasaran anggarannya jelas, akan lebih bertanggungjawab jika didukung oleh komitmen aparat yang tinggi terhadap organisasi (instansi) pemerintahan daerah. Aparat akan lebih mementingkan kepentingan organisasi daripada kepentingan pribadi. Hal ini akan mendorong aparat untuk menyusun anggaran sesuai dengan sasaran yang ingin dicapai organisasi sehingga akan mengurangi terjadinya senjangan anggaran. Berdasarkan APBD Kabupaten Tabanan dan ketidakkonsistenan hasil penelitian sebelumnya maka penelitian ini bertujuan untuk menguji kembali pengaruh asimetri informasi pada senjangan anggaran dengan kejelasan sasaran anggaran dan komitmen organisasi sebagai variabel pemoderasi pada Dinas Pemerintah Kabupaten Tabanan. Penelitian ini diharapkan dapat menambah wawasan ilmu kepada akademisi mengenai penerapan teori keagenan dan teori kontinjensi dalam senjangan anggaran yang telah dipelajari dengan kenyataan yang terjadi di lapangan, dan bertujuan untuk mengembangkan ilmu pengetahuan mengenai pengaruh yang ditimbulkan dari kejelasan sasaran anggaran dan komitmen organisasi terhadap asimetri informasi dan senjangan anggaran.

Teori keagenan dipergunakan untuk menganalisis hubungan prinsipal-agen dalam kaitannya dengan penganggaran sektor publik. Teori keagenan 
menganalisis susunan kontraktual di antara dua atau lebih individu, kelompok atau organisasi. Salah satu pihak (principal) membuat suatu kontrak, baik secara implisit maupun eksplisit dengan pihak lain (agents) dengan harapan bahwa agen akan bertindak melakukan pekerjaan seperti yang diinginkan principal (Jensen dan Meckling, 1976). Latuheru (2005) menyatakan bahwa praktik senjangan anggaran dalam perspektif agency theory dipengaruhi oleh adanya konflik kepentingan antara manajemen dengan prinsipal yang timbul ketika setiap pihak berusaha untuk mencapai atau mempertahankan tingkat kemakmuran yang dikehendakinya. Jika bawahan (agent) yang berpartisipasi dalam proses penyusunan anggaran mempunyai informasi khusus tentang kondisi lokal, akan memungkinkan bawahan memberikan informasi yang dimilikinya untuk membantu kepentingan perusahaan. Namun, sering keinginan atasan tidak sama dengan bawahan sehingga menimbulkan konflik diantara mereka. Hal ini dapat terjadi misalnya, jika dalam melakukan kebijakan pemberian rewards perusahaan kepada bawahan didasarkan pada pencapaian anggaran. Bawahan cenderung memberikan informasi yang bias agar anggaran mudah dicapai dan mendapatkan rewards berdasarkan pencapaian (Latuheru, 2005).

Teori kontinjensi pada awalnya diperkenalkan oleh Lawrence dan Lorsch (1967) yang menyatakan bahwa sebuah organisasi tidak memiliki metode terbaik dalam memperoleh keserasian antara faktor lingkungan internal organisasi maupun faktor lingkungan eksternal untuk dapat mencapai prestasi terbaik. Islam dan Hui (2012) juga menyatakan teori kontinjensi sebagai pendekatan untuk mempelajari perilaku organisasi dimana penjelasan diberikan sebagai faktor 
Ni Made Kusuma Ayuni dan Ni Made Adi Erawati. Pengaruh ...

kontingen mempengaruhi fungsi organisasi. Pendekatan kontinjensi perlu dilakukan karena adanya inkonsistensi pada hasil penelitian terdahulu sehingga ketidakpastian faktor-faktor kondisional yang dapat mempengaruhi efektivitas perumusan anggaran terhadap senjangan anggaran perlu dievaluasi.

Penggunaan pendekatan kontinjensi memungkinkan adanya variabelvariabel lain yang dapat bertindak sebagai variabel moderating atau variabel intervening yang mempengaruhi hubungan asimetri informasi dengan senjangan anggaran. Dalam penelitian ini, pendekatan kontinjensi diadopsi untuk mengevaluasi keefektifan hubungan antara asimetri informasi terhadap senjangan anggaran. Faktor kontinjensi yang dipilih dalam penelitian ini adalah kejelasan sasaran anggaran dan komitmen organisasi. Faktor kontinjensi yang telah dipilih tersebut akan berperan sebagai variabel moderasi dalam hubungan antara asimetri informasi terhadap senjangan anggaran.

Hubungan keagenan antara manajer atas dengan manajer bawah tidak jarang sering menimbulkan masalah mengenai kesenjangan informasi, dimana manajer atas kurang memiliki informasi terkait unit ataupun pusat tanggung jawab yang dikelola oleh manajer bawah. Kesenjangan informasi inilah yang kemudian disebut asimetri informasi. Busuioc (2011) menyebutkan bahwa asimetri informasi mengacu pada ketidakpastian yang disebabkan karena agen mempunyai informasi pribadi yang lebih banyak tentang bidangnya dibandingkan dengan prinsipal. Asimetri informasi sering kali dimanfaatkan oleh bawahan untuk memenuhi kebutuhan pribadinya (Saad, 2002), dimana bawahan cenderung memberikan informasi bias kepada atasannya, seperti menaikkan biaya atau 
menurunkan pendapatan. Manajer bawah seringkali memanfaatkan kondisi tersebut untuk menciptakan senjangan anggaran.

Rukmana (2013) menyebutkan bahwa asimetri informasi berpengaruh positif terhadap budgdetary slack. Semakin tinggi asimetri informasi yang ada, maka akan semakin tinggi juga budgetary slack yang terjadi. Penelitian Latif (2013) menyatakan informasi asimetri berpengaruh secara signifikan terhadap senjangan anggaran dengan arah postif. Dimana ketika asimetri meningkat dalam proses penyusunan anggaran, maka akan memicu meningkatnya senjangan anggaran. Semakin tinggi asimetri informasi maka akan semakin tinggi senjangan anggaran yang terjadi. Serta hasil penelitian Djasuli dan Fadilah (2011) menyatakan asimetri informasi berpengaruh positif dan signifikan pada senjangan anggaran. Aprila (2012) menyatakan bahwa interaksi asimetri informasi merupakan faktor utama penyebab timbulnya senjangan anggaran. Berdasarkan penjelasan tersebut, maka hipotesis yang diajukan dalam penelitian ini adalah.

$\mathrm{H}_{1}$ : Asimetri informasi berpengaruh positif pada senjangan anggaran Dinas Pemerintah Kabupaten Tabanan.

Kejelasan sasaran anggaran akan mendorong manajer lebih efektif dan melakukan yang terbaik dibandingkan dengan sasaran yang tidak jelas. Locke (1968) menyatakan bahwa penentuan sasaran anggaran secara spesifik lebih produktif dibandingkan jika tidak ada penentuan sasaran. Adanya sasaran anggaran yang jelas, akan mempermudah untuk mempertanggungjawabkan keberhasilan atau kegagalan pelaksanaan tugas organisasi dalam rangka untuk mencapai tujuan-tujuan dan sasaran-sasaran yang telah ditetapkan sebelumnya. Sasaran yang tidak jelas dapat menyebabkan kebingungan, tekanan dan 
Ni Made Kusuma Ayuni dan Ni Made Adi Erawati. Pengaruh ...

ketidakpuasan dari pegawai. Pimpinan organisasi dapat meningkatkan kepuasan kerja, menurunkan ketegangan kerja, dan memperbaiki anggaran yang dihubungkan dengan sikap, kinerja anggaran, dan efisiensi biaya. Oleh sebab itu, kejelasan sasaran anggaran daerah harus dinyatakan secara jelas, spesifik dan dapat dimengerti oleh mereka yang bertanggung-jawab untuk menyusun dan melaksanakannya.

Penelitian yang dilakukan oleh Suhartono dan Solichin (2006), Agusti (2013), dan Pitasari dkk., (2014) , dan Putri (2016) yang menyatakan bahwa kejelasan sasaran anggaran mempunyai pengaruh negatif terhadap senjangan anggaran. Semakin tinggi tingkat kejelasan sasaran dari anggaran tersebut, maka resiko terjadinya senjangan anggaran akan semakin rendah. Berdasarkan uraian tersebut, maka hipotesis yang diajukan dalam penelitian ini adalah.

$\mathrm{H}_{2}$ : Kejelasan sasaran anggaran memperlemah pengaruh asimetri informasi pada senjangan anggaran di Dinas Pemerintah Kabupaten Tabanan

Hubungan teori keagenan dalam organisasi dapat mengakibatkan asimetri informasi, dimana manajemen secara umum memiliki lebih banyak informasi mengenai posisi keuangan yang sebenarnya dan dapat menimbulkan konflik kepentingan akibat ketidaksamaan tujuan dari agen dan prinsipal. Dorongan dari dalam diri individu untuk berbuat sesuatu agar dapat menunjang keberhasilan organisasi sesuai dengan tujuan dan lebih mengutamakan kepentingan organisasi disebut komitmen organisasi (Wiener, 1982). Berkaitan dengan penelitian mengenai komitmen organisasi, Nouri dan Parker (1996) berpendapat bahwa naik atau turunnya senjangan anggaran tergantung pada apakah individu memilih untuk mengejar kepentingan diri sendiri atau justru bekerja untuk kepentingan 
organisasi. Komitmen yang tinggi menjadikan individu peduli dengan nasib organisasi dan berusaha menjadikan organisasi ke arah yang lebih baik.

Penelitian yang dilakukan Latuheru (2005) dan Citra Dewi (2013) yang menyatakan bahwa komitmen organisasi mempunyai pengaruh signifikan negatif terhadap senjangan anggaran. Penelitian Kartika (2010) menyebutkan bahwa komitmen organisasi berpengaruh negatif terhadap senjangan anggaran. Serta penelitian Desmiyawati (2009) menyatakan pengaruh komitmen organisasi terhadap senjangan anggaran dengan hasil negatif. Dengan memiliki komitmen yang tinggi terhadap organisasi akan menjadikan individu lebih peduli akan nasib organisasinya dan akan lebih berusaha sebaik mungkin untuk menjadikan organisasi tersebut kearah yang lebih baik, dan kecenderungan terjadinya kesenjangan akan terhindari.Berdasarkan penjelasan tersebut, maka hipotesis yang diajukan adalah.

$\mathrm{H}_{3}$ : Komitmen organisasi memperlemah pengaruh asimetri informasi pada senjangan anggaran Dinas Pemerintah Kabupaten Tabanan.

\section{METODE PENELITIAN}

Penelitian ini dilakukan pada Satuan Kerja Perangkat Daerah (SKPD) yang berupa seluruh dinas pemerintahan di Kabupaten Tabanan yang berjumlah 19 (sembilan belas) dinas. Obyek penelitian yang digunakan yaitu senjangan anggaran yang dipengaruhi oleh variabel asimetri informasi dengan kejelasan sasaran anggaran dan komitmen anggaran sebagai variabel pemoderasi. Pendekatan yang digunakan dalam penelitian ini adalah pendekatan kuantitatif yang berbentuk assosiatif. Adapun gambar desain dalam penelitian ini adalah sebagai berikut. 


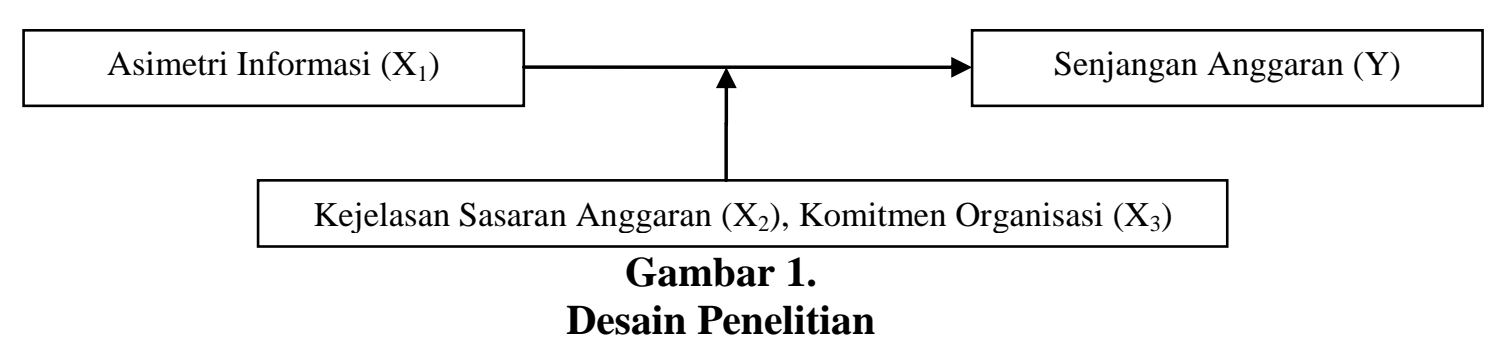

Sumber: Data diolah, 2017

Jenis data yang digunakan dalam penelitian ini adalah data kuantitatif dan data kualitatif. Data kuantitatif dalam penelitian ini adalah jawaban dari responden atas pertanyaan yang terdapat dalam kuesioner yang telah disebar oleh peneliti mengenai asimetri informasi, senjangan anggaran, kejelasan sasaran anggaran, dan komitmen organisasi yang telah diangkakan dengan menggunakan skala likert. Data kualitatif dalam penelitian ini adalah daftar jumlah Dinas Pemerintah Kabupaten Tabanan. Sumber data dalam penelitian ini adalah data primer yaitu berupa data yang diperoleh dari jawaban responden terhadap kuesioner yang telah diajukan kepada responden tersebut.

Variabel bebas dalam penelitian ini adalah asimetri informasi. Asimetri informasi merupakan keadaan dimana bawahan memiliki informasi lebih banyak dibandingkan dengan informasi yang dimiliki oleh atasan. Indikator pengukuran variabel asimetri informasi $\left(\mathrm{X}_{1}\right)$ yang dikembangkan oleh Dunk (1993) yaitu keadaan dimana manajemen memiliki informasi yang lebih baik atas aktivitas, keadaan dimana manajemen lebih mengetahui potensi kinerja, dan keadaan dimana manajemen lebih mengetahui teknis pekerjaan. Variabel asimetri informasi disajikan dalam bentuk daftar pertanyaan, terdiri dari 5 (lima) pernyataan yang diadopsi dari penelitian Latuheru (2005) dengan menggunakan skala Likert 1-4, yaitu 1 berarti Sangat Tidak Setuju (STS) yang menunjukkan 
asimetri informasi yang sangat rendah sampai skala 4 yang artinya Sangat Setuju (SS) yang menunjukkan asimetri informasi yang sangat tinggi.

Variabel terikat dalam penelitian ini adalah senjangan anggaran. Senjangan anggaran merupakan selisih antara anggaran dengan realisasinya. Senjangan anggaran biasa dilakukan dengan menetapkan biaya yang lebih tinggi dari biaya yang sesungguhnya. Indikator dari variabel senjangan anggaran (Y) terdiri dari standar penyusunan anggaran, monitoring anggaran dan pencapaian anggaran. Variabel senjangan anggaran diukur dengan 6 (enam) pernyataan yang diadopsi dari Mahadewi (2014) dengan menggunakan skala Likert 1-4.

Variabel moderasi dalam penelitian ini adalah kejelasan sasaran anggaran dan komitmen organisasi. Kejelasan sasaran anggaran merupakan sejauh mana tujuan anggaran ditetapkan secara jelas dan spesifik dengan tujuan agar anggaran tersebut dapat dimengerti oleh orang yang bertanggungjawab atas pencapaian sasaran anggaran tersebut. Oleh sebab itu sasaran anggaran pemerintah daerah harus dinyatakan secara jelas, spesifik dan dapat dimengerti oleh mereka yang bertanggung jawab untuk melaksanakannya. Indikator yang digunakan dalam mengukur kejelasan sasaran anggaran yang dikembangkan oleh Putra (2013) yaitu memahami jenis pekerjaan, kinerja, batas waktu pencapaian sasaran, sasaran yang jelas, alternartif sasaran, kualitas sasaran, dan kerjasama tim. Variabel kejelasan sasaran anggaran disajikan dalam bentuk daftar pertanyaan, terdiri dari 7 (tujuh) pernyataan dengan menggunakan skala Likert 1-4.

Komitmen organisasional didefinisikan sebagai kesediaan individu terlibat dalam organisasi melalui penerimaan nilai-nilai organisasi, kesediaan atau 
Ni Made Kusuma Ayuni dan Ni Made Adi Erawati. Pengaruh ...

kemauan untuk berusaha menjadi bagian dari organisasi, serta keinginan untuk bertahan di dalam organisasi (Meyerd dan Allen, 1993). Untuk mengukur komitmen organisasi, digunakan 9 (sembilan) item pernyataan yang dikembangkan oleh Cook dan Wall (1980) dengan indikator komitmen organisasional yaitu komitmen afektif (affective commitment), komitmen normatif (normative commitment), komitmen berkelanjutan (continuance commitment). Variabel kejelasan sasaran anggaran disajikan dalam bentuk daftar pertanyaan terdiri dari 9 (sembilan) pertanyaan dengan menggunakan skala Likert 1-4, Alasan menggunakan skala Likert empat poin adalah dengan pertimbangan untuk memperoleh pandangan responden secara lebih jelas mengenai pertanyaanpertanyaan yang disajikan dalam kuesioner.

Populasi penelitian ini adalah SKPD berupa Dinas Pemerintah Kabupaten Tabanan. Teknik penentuan sampel dalam penelitian ini adalah berdasarkan sampel jenuh (sensus) dengan menggunakan seluruh populasi. Penentuan sampel dengan teknik sampel jenuh dipertimbangkan karena ketersediaan waktu dan jumlah yang memungkinkan untuk dilakukan penelitian secara keseluruhan. Responden sampel yang digunakan dalam penelitian ini adalah Kepala Dinas, Kepala Sub Bagian Umum dan Perencanaan, serta Kepala Sub Bagian Keuangan karena ketiganya ikut berpartisipasi dalam penyusunan anggaran.

Metode pengumpulan data yang digunakan dalam penelitian ini adalah metode survei dengan teknik kuesioner, yaitu teknik pengumpulan data yang dilakukan dengan cara memberi seperangkat pertanyaan tertulis kepada responden untuk dijawab (Sugiyono, 2014:199). Kuesioner akan didistribusikan secara 
langsung ke seluruh daftar Dinas Pemerintahan di Kabupaten Tabanan. Teknik analisis yang digunakan untuk menguji hipotesis pertama mengenai pengaruh asimetri informasi pada senjangan anggaran akan dianalisis dengan menggunakan alat analisis regresi linier sederhana. Persamaan statistik yang digunakan adalah:

$\mathrm{Y}=\alpha+\beta_{1} \mathrm{X}_{1}+\mathrm{e}$

Keterangan:

$\mathrm{Y} \quad=$ Senjangan Anggaran

$\alpha \quad=$ Konstanta

$\mathrm{B}_{1} \quad=$ Koefisien regresi

$\mathrm{X}_{1} \quad=$ Asimetri Informasi

e $\quad=$ error

Model analisis data dan uji hipotesis dalam penelitian ini adalah model analisis regresi moderasi (moderated regression analysis). Analisis regresi ini merupakan aplikasi khusus regresi linier berganda yang mana dalam persamaan regresinya mengandung unsur interaksi (perkalian dua atau lebih variabel independen). Bentuk regresi ini dirancang untuk menentukan hubungan antar dua variabel yang dipengaruhi oleh variabel moderasi (Suliyanto, 2011).

Secara sistematis diperoleh persamaan regresi:

$Y=\alpha+\beta_{1} X_{1}+\beta_{2} X_{2}+\beta_{3} X_{3}+\beta_{4} X_{1} \cdot X_{2}+\beta_{5} X_{1} \cdot X_{3}+e$

Keterangan:

$\mathrm{Y} \quad=$ Senjangan anggaran

$\mathrm{X}_{1} \quad=$ Asimetri informasi

$\mathrm{X}_{2} \quad=$ Kejelasan sasaran anggaran

$\mathrm{X}_{3} \quad=$ Komitmen organisasi

$\alpha \quad=$ Konstanta

$\beta_{1}-\beta_{5}=$ Koefisien regresi

$\mathrm{X}_{1} \cdot \mathrm{X}_{2}=$ Interaksi antara asimetri informasi dengan kejelasan sasaran anggaran.

$\mathrm{X}_{1} \cdot \mathrm{X}_{3}=$ Interaksi antara asimetri informasi dengan komitmen organisasi

$\mathrm{e} \quad=$ error atau variabel pengganggu. 
Ni Made Kusuma Ayuni dan Ni Made Adi Erawati. Pengaruh ...

\section{HASIL DAN PEMBAHASAN}

Penelitian ini dilakukan untuk meneliti pengaruh asimetri informasi pada senjangan anggaran dengan kejelasan sasaran anggaran dan komitmen organisasi sebagai variabel pemoderasi. Responden dalam penelitian ini adalah pegawai SKPD berupa Dinas Pemerintah Kabupaten Tabanan yang ikut dalam penyusunan anggaran dengan unit analisis yang digunakan dalam penelitian ini adalah Kepala SKPD, Kepala Sub Bagian Umum dan Perencanaan, serta Kepala Sub Bagian Keuangan. Data dikumpulkan dengan cara menyebarkan kuesioner secara langsung dilakukan oleh peneliti. Sehingga sampel yang digunakan dalam penelitian ini berjumlah 57 orang.

Tabel 3.

Hasil Statistik Deskriptif

\begin{tabular}{|c|c|c|c|c|c|}
\hline Variabel & $\mathbf{N}$ & Minimum & Maximum & Mean & Std. Deviasi \\
\hline Asimetri Informasi $\left(\mathrm{X}_{1}\right)$ & 57 & 5,00 & 18,25 & 10,2526 & 3,94173 \\
\hline Kejelasan Sasaran Anggaran $\left(\mathrm{X}_{2}\right)$ & 57 & 7,00 & 25,93 & 20,5826 & 6,14005 \\
\hline Komitmen Organisasi $\left(\mathrm{X}_{3}\right)$ & 57 & 9,00 & 33,67 & 26,8112 & 7,78495 \\
\hline Senjangan Anggaran (Y) & 57 & 6,00 & 20,70 & 11,4577 & 4,63329 \\
\hline Valid N (listwise) & 57 & & & & \\
\hline
\end{tabular}

Sumber: Data diolah, 2017

Berdasarkan Tabel 3. dapat dilihat nilai minimum untuk asimetri informasi $\left(\mathrm{X}_{1}\right)$ adalah 5,0 dan nilai maksimumnya adalah 18,25 . Mean untuk asimetri informasi adalah 10,25, hal ini berarti rata-rata asimetri informasi sebesar 10,25. Standar deviasinya 3,94, hal ini berarti perbedaan nilai asimetri informasi yang diteliti terhadap nilai rata-rata sebesar 3,94. Untuk variabel kejelasan sasaran anggaran nilai minimumnya adalah 7,0 dan nilai maksimumnya adalah 25,93. Mean untuk kejelasan sasaran anggaran adalah 20,58, hal ini berarti rata-rata kejelasan sasaran anggaran sebesar 20,58. Standar deviasi untuk kejelasan sasaran 
anggaran sebesar 6,14, yang berarti perbedaan nilai kejelasan sasaran anggaran yang diteliti terhadap nilai rata-rata sebesar 6,14.

Variabel komitmen organisasi nilai minimumnya adalah 9,00 dan nilai maksimumnya adalah 33,67. Mean untuk komitmen organisasi adalah 26,81, hal ini berarti rata-rata komitmen organisasi sebesar 26,81. Standar deviasi untuk komitmen organisasi sebesar 7,78 yang berarti perbedaan nilai komitmen organisasi yang diteliti terhadap nilai rata-rata sebesar 7,78. Untuk variabel senjangan anggaran nilai minimumnya adalah 6,00 dan nilai maksimumnya adalah 20,70. Mean untuk senjangan anggaran adalah 11,46, hal ini berarti ratarata senjangan anggaran sebesar 11,46. Standar deviasi untuk senjangan anggaran sebesar 4,63, yang berarti perbedaan nilai senjangan anggaran yang diteliti terhadap nilai rata-rata sebesar 4,63.

Validnya suatu kuesioner dapat dilihat dari nilai $\mathrm{r}$ hitung yang lebih besar dari 0,30 pada pearson correlation. Instrumen penelitian ini yang terdiri dari item-item pertanyaan dan pernyataan senjangan anggaran $(\mathrm{Y})$, asimetri informasi $\left(\mathrm{X}_{1}\right)$, kejelasan sasaran anggaran $\left(\mathrm{X}_{2}\right)$, dan komitmen organisasi $\left(\mathrm{X}_{3}\right)$ adalah valid. Hal ini dikarenakan nilai korelasi yang diperoleh antara skor masing-masing pertanyaan dan pernyataan dengan skor total besarnya diatas 0,30 .

\section{Tabel 4.}

Hasil Uji Reliabilitas Instrumen

\begin{tabular}{clcc}
\hline No & \multicolumn{1}{c}{ Variabel } & Cronbach's Alpha & Keterangan \\
\hline 1 & Senjangan Anggaran $(\mathrm{Y})$ & 0,891 & Reliabel \\
2 & Asimetri Informasi $\left(\mathrm{X}_{1}\right)$ & 0,849 & Reliabel \\
3 & Kejelasan Sasaran & 0,962 & Reliabel \\
4 & Anggaran $\left(\mathrm{X}_{2}\right)$ & 0,960 & Reliabel \\
\hline
\end{tabular}

Sumber: Data diolah, 2017 
Berdasarkan Tabel 4 dapat dilihat bahwa nilai cronbach's alpha masing-masing variabel memiliki nilai lebih besar dari 0,60. Hal ini berarti semua pertanyaan dan pernyataan dalam kuesioner penelitian ini reliabel dan dapat digunakan.

Berdasarkan hasil uji normalitas untuk regresi linier sederhana menunjukkan koefisien Asymp. Sig. (2-tailed) sebesar 0,200 yang lebih besar dari 0,05. Hal ini berarti data dalam penelitian ini berdistribusi normal. Berdasarkan hasil uji heteroskedastisitas untuk regresi linier sederhana dapat diketahui bahwa nilai signifikansi untuk variabel asimetri informasi $\left(\mathrm{X}_{1}\right)$ adalah 0,236 lebih besar dari 0,05 , yang artinya regresi yang digunakan dalam penelitian ini bebas dari gejala heterokedastisitas. Berdasarkan hasil uji normalitas untuk regresi linier berganda menunjukkan koefisien Asymp. Sig. (2-tailed) sebesar 0,200 yang lebih besar dari 0,05 . Hal ini berarti data dalam penelitian ini berdistribusi normal. Berdasarkan hasil uji heteroskedastisitas untuk regresi linier berganda diketahui bahwa nilai signifikansi pada masing-masing variabel memiliki nilai lebih besar dari 0,05 , yang artinya regresi yang digunakan dalam penelitian ini bebas dari gejala heteroskedastisitas. Berdasarkan hasil tersebut dapat dinyatakan bahwa model regresi dalam penelitian ini telah lolos uji asumsi klasik.

Tabel 5.

Hasil Pengujian Regresi Linier Sederhana

\begin{tabular}{|c|c|c|c|c|c|c|}
\hline & \multirow[t]{2}{*}{ Model } & \multicolumn{2}{|c|}{ Unstandardized Coefficients } & \multirow{2}{*}{$\begin{array}{c}\begin{array}{c}\text { Standardized } \\
\text { Coefficients }\end{array} \\
\text { Beta } \\
\end{array}$} & \multirow[t]{2}{*}{$\mathbf{t}$} & \multirow[t]{2}{*}{ Sig. } \\
\hline & & B & Std. Error & & & \\
\hline \multirow[t]{2}{*}{1} & (Constant) & 4,451 & 1,415 & & 3,146 & ,003 \\
\hline & $\mathrm{X}_{1}$ & ,683 &, 129 &, 581 & 5,299 &, 000 \\
\hline
\end{tabular}

Sumber: Data diolah, 2017

Nilai konstanta pada tabel 5 sebesar 4,451 memiliki arti jika asimetri informasi sama dengan nol, maka terdapat senjangan anggaran sebesar 4,451\%. 
ISSN: 2302-8556

E-Jurnal Akuntansi Universitas Udayana

Vol.22.1. Januari (2018): 492-520

Nilai koefisien $\left(\beta_{1}\right)$ sebesar 0,683 berarti jika asimetri informasi bertambah 1 (satu), maka nilai dari senjangan anggaran akan meningkat sebesar 0,683 atau apabila nilai asimetri informasi meningkat $1 \%$ maka senjangan anggaran akan meningkat sebesar 0,638\% dengan syarat variabel lain konstan.

Tabel 6.

Hasil Pengujian Regresi Moderasi

\begin{tabular}{|c|c|c|c|c|c|c|}
\hline & \multirow[t]{2}{*}{ Model } & \multicolumn{2}{|c|}{ Unstandardized Coefficients } & \multirow{2}{*}{$\begin{array}{c}\text { Standardized } \\
\text { Coefficients } \\
\text { Beta } \\
\end{array}$} & \multirow[t]{2}{*}{$\mathbf{T}$} & \multirow[t]{2}{*}{ Sig. } \\
\hline & & $\mathbf{B}$ & Std. Error & & & \\
\hline \multirow[t]{6}{*}{1} & (Constant) & 17,079 & 6,358 & & 2,686 & ,010 \\
\hline & $\mathrm{X}_{1}$ &, 582 & ,418 & ,495 & 1,391 & 170 \\
\hline & $\mathrm{X}_{2}$ &, 186 & 225 & ,246 & ,826 & ,413 \\
\hline & $\mathrm{X}_{3}$ &,- 371 &, 174 &,- 623 & $-2,135$ & ,038 \\
\hline & $\mathrm{X}_{1 \_} \mathrm{X}_{2}$ &,- 040 & ,017 &,- 607 & $-2,276$ & ,027 \\
\hline & $\mathrm{X}_{1-\mathrm{X}_{3}}$ & ,009 &, 014 &, 161 &, 650 &, 519 \\
\hline
\end{tabular}

Sumber: Data diolah, 2017

Berdasarkan tabel 6 dapat diketahui nilai konstanta (a) sebesar 17,079 memiliki arti apabila asimetri informasi $\left(\mathrm{X}_{1}\right)$, kejelasan sasaran anggaran $\left(\mathrm{X}_{2}\right)$, komitmen organisasi $\left(\mathrm{X}_{3}\right)$ sama dengan nol, maka nilai senjangan anggaran $(\mathrm{Y})$ sebesar 17,079 satuan. Nilai koefisien regresi $\left(\beta_{1}\right)$ pada variabel asimetri informasi $\left(\mathrm{X}_{1}\right)$ sebesar 0,582 . Koefisien regresi yang bernilai positif memiliki arti jika asimetri informasi meningkat sebesar satu satuan, maka senjangan anggaran akan meningkat sebesar 0,582 satuan. Nilai koefisien regresi $\left(\beta_{2}\right)$ kejelasan sasaran anggaran $\left(\mathrm{X}_{2}\right)$ sebesar 0,186 . Koefisien regresi yang bernilai positif memiliki arti apabila kejelasan sasaran anggaran meningkat sebesar satu satuan dengan anggapan variabel lainnya konstan, maka senjangan anggaran (Y) akan meningkat sebesar 0,186 satuan.

Nilai koefisien regresi $\left(\beta_{3}\right)$ komitmen organisasi $\left(\mathrm{X}_{3}\right)$ sebesar $-0,371$. Koefisien regresi yang bernilai negatif memiliki arti apabila komitmen organisasi meningkat 1 satuan dengan anggapan variabel lainnya konstan, maka senjangan 
Ni Made Kusuma Ayuni dan Ni Made Adi Erawati. Pengaruh ...

anggaran (Y) mengalami penurunan sebesar 0,371 satuan. Nilai koefisien regresi $\left(\beta_{4}\right)$ sebesar $-0,040$, merupakan hasil perkalian variabel asimetri informasi dengan kejelasan sasaran anggaran artinya jika interaksi antara asimetri dan kejelasan sasaran anggaran naik sebesar satu satuan, maka akan menurunkan senjangan anggaran sebesar 0,040 satuan. Nilai koefisien regresi $\left(\beta_{5}\right)$ sebesar 0,009 . merupakan hasil perkalian variabel asimetri informasi dengan komitmen organisasi artinya jika interaksi antara asimetri informasi dan komitmen organisasi naik sebesar satu satuan, maka akan menaikkan senjangan anggaran sebesar 0,009 satuan.

\section{Tabel 7.}

Hasil Adjusted R Square untuk model regresi linier sederhana

\begin{tabular}{crrrrr}
\hline Model & $\mathbf{R}$ & $\boldsymbol{R}$ Square & $\begin{array}{c}\text { Adjusted } \boldsymbol{R} \\
\text { Square }\end{array}$ & \multicolumn{1}{c}{ Std. Error of the Estimate } \\
\hline 1 &, $581^{\mathrm{a}}$ &, 338 &, 326 & 3,80393 \\
\hline
\end{tabular}

Sumber: Data diolah, 2017

Nilai adjusted $R$ square $\left(\mathrm{R}^{2}\right)$ pada Tabel 7 sebesar 0,338 memiliki arti bahwa 33,8\% variasi senjangan anggaran dapat dijelaskan oleh variasi dari asimetri informasi, sedangkan sisanya sebesar $66,2 \%$ dijelaskan oleh faktor lain diluar model.

Tabel 8.

Hasil Adjusted R Square pada Model Regresi Moderasi

\begin{tabular}{crrrr}
\hline Model & $\mathbf{R}$ & $\boldsymbol{R}$ Square & Adjusted R Square & Std. Error of the Estimate \\
\hline 1 &, $836^{\mathrm{a}}$ &, 699 &, 669 & 2,66472 \\
\hline
\end{tabular}

Sumber: Data diolah, 2017

Nilai adjusted $R$ square $\left(\mathrm{R}^{2}\right)$ pada Tabel 8 sebesar 0,669 memiliki arti bahwa 66,9\% perubahan yang terjadi pada senjangan anggaran dipengaruhi/dijelaskan oleh kejelasan sasaran anggaran, komitmen organisasi, interaksi antara asimetri informasi dengan kejelasan sasaran anggaran, dan 
ISSN: 2302-8556

E-Jurnal Akuntansi Universitas Udayana

Vol.22.1. Januari (2018): 492-520

interaksi antara asimetri informasi dan komitmen organisasi, sementara sisanya 33,1\% dipengaruhi/dijelaskan oleh variabel-variabel lain diluar model penelitian.

Tabel 9.

Hasil Uji F Regresi Linier Sederhana

\begin{tabular}{rlrrrrr}
\hline \multirow{2}{*}{ Model } & \multicolumn{1}{c}{$\begin{array}{c}\text { Sum } \text { of } \\
\text { Squares }\end{array}$} & Df & $\begin{array}{c}\text { Mean } \\
\text { Square }\end{array}$ & \multicolumn{1}{c}{ F } & \multicolumn{1}{c}{ Sig. } \\
\hline \multirow{2}{*}{1} & Regression & 406,331 & 1 & 406,331 & 28,081 &, $000^{\mathrm{b}}$ \\
& Residual & 795,843 & 55 & 14,470 & & \\
& Total & 1202,174 & 56 & & & \\
\hline
\end{tabular}

Sumber: Data diolah, 2017

Tabel 9 menunjukkan nilai $\mathrm{F}$ sebesar 28,081 dengan signifikansi 0,000 yang berarti nilai signifikansi lebih kecil dari $\alpha=0,05$, ini berarti model yang digunakan pada penelitian ini adalah layak uji. Hal ini memberikan makna bahwa variabel asimetri informasi mampu memprediksi atau menjelaskan fenomena senjangan anggaran.

Tabel 10.

Hasil Uji F Regresi Moderasi

\begin{tabular}{|c|c|c|c|c|c|c|}
\hline & Model & $\begin{array}{l}\text { Sum of } \\
\text { Squares }\end{array}$ & Df & $\begin{array}{l}\text { Mean } \\
\text { Square }\end{array}$ & $\mathbf{F}$ & Sig. \\
\hline \multirow{3}{*}{1} & Regression & 840,038 & 5 & 168,008 & 23,661 &, $000^{b}$ \\
\hline & Residual & 362,136 & 51 & 7,101 & & \\
\hline & Total & 1202,174 & 56 & & & \\
\hline
\end{tabular}
Sumber: Data diolah, 2017

Berdasarkan Tabel 10 dapat dilihat bahwa nilai $\mathrm{F}$ sebesar 23,661 dengan signifikansi 0,000 yang berarti nilai signifikansi lebih kecil dari 0,05, hal ini berarti bahwa asimetri informasi, kejelasan sasaran anggaran, komitmen organisasi, interaksi antara asimetri informasi dengan kejelasan sasaran anggaran dan interaksi antara asimetri informasi dengan komitmen organisasi secara bersama-sama berpengaruh pada senjangan anggaran sehingga model yang digunakan pada penelitian ini adalah layak uji. 
Ni Made Kusuma Ayuni dan Ni Made Adi Erawati. Pengaruh ...

Pada tabel 5 dapat dilihat bahwa asimetri informasi memiliki nilai $\beta_{1}$ sebesar 0,683 dengan tingkat signifikansi sebesar 0,000 lebih kecil dari alpha 0,05. Artinya terdapat pengaruh positif asimetri informasi pada senjangan anggaran. Hal ini berarti $\mathrm{H}_{0}$ ditolak dan $\mathrm{H}_{1}$ diterima, yang artinya hipotesis 1 yang menyatakan asimetri informasi berpengaruh positif pada senjangan anggaran diterima $\left(\mathrm{H}_{1}\right.$ diterima). Hasil dari penelitian ini menunjukkan bahwa jika informasi Kepala Sub Bagian lebih baik dari Kepala Dinas atau terdapat asimetri informasi yang membuat anggaran relatif lebih mudah dicapai, sehingga terjadilah senjangan anggaran yaitu dengan melaporkan anggaran di bawah kinerja yang diharapkan. Dengan kata lain informasi asimetri memberikan pengaruh yang signifikan pada senjangan anggaran.

Berdasarkan teori keagenan manusia akan bertindak opportunistik yaitu mengutamakan kepentingan pribadi daripada kepentingan orgasinasi. Kepala Dinas tidak dapat memonitoring kegiatan Kepala Sub Bagian setiap hari, sebaliknya Kepala Sub Bagian mengetahui informasi penting mengenai kapasitas diri, lingkungan kerja, dan organisasi secara keseluruhan. Hal inilah yang menimbulkan asimetri informasi yaitu ketidakseimbangan informasi antara atasan dan bawahan. Hasil penelitian ini mendukung penelitian yang dilakukan oleh Rukmana (2013), Latif (2013), Djasuli dan Fadilah (2011), dan Young (1985) yang menyatakan bahwa asimetri informasi berpengaruh positif dan signifikan terhadap senjangan anggaran

Pada tabel 6 diperoleh nilai signifikansi dari $t_{\text {hitung }}$ untuk variabel moderasi kejelasan sasaran anggaran berpengaruh pada hubungan antara asimetri informasi 
dengan senjangan anggaran sebesar 0,027 , nilai ini lebih kecil dari $\alpha=0,05$ $(0,027<0,05)$. Nilai koefisien $\left(b_{4}\right)$ bernilai negatif sebesar $-0,040$. Hasil ini menunjukkan bahwa kejelasan sasaran anggaran $\left(\mathrm{X}_{2}\right)$ mampu memperlemah pengaruh asimetri dengan senjangan anggaran, yang berarti hipotesis kedua diterima. Dengan adanya informasi yang jelas, tepat waktu, dan obyektif maka anggaran dapat ditetapkan secara jelas dan tepat agar lebih mudah dimengerti.

Teori keagenan menjelaskan fenomena pemberian wewenang dari atasan kepada bawahan untuk bertanggungjawab melakukan suatu tugas dan keputusan. Dalam penelitian ini variabel kejelasan sasaran anggaran dapat menjadi variabel pemoderasi sehingga mendukung adanya teori kontinjensi. Hasil penelitian ini menunjukan adanya kejelasan sasaran anggaran yang jelas dan spesifik maka akan mudah dimengerti oleh yang bertanggungjawab atas pencapaian anggaran tersebut dan mengurangi terjadinya senjangan anggaran. Hasil penelitian ini mendukung penelitian yang dilakukan oleh Suhartono dan Solichin (2006), Agusti (2013), dan Pitasari dkk., (2014), dan Putri (2016) yang menyatakan bahwa kejelasan sasaran anggaran mampu memperlemah pengaruh asimetri informasi terhadap senjangan anggaran.

Pada tabel 6 dapat dilihat bahwa interaksi antara variabel asimetri informasi dengan variabel komitmen organisasi memiliki tingkat signifikansi sebesar 0,519 lebih besar dari alpha 0,05, Nilai koefisien $\left(b_{5}\right)$ bernilai positif sebesar 0,009. Hasil ini menunjukkan bahwa komitmen organisasi $\left(\mathrm{X}_{3}\right)$ tidak mampu memoderasi pengaruh asimetri dengan senjangan anggaran, hal ini berarti $\mathrm{H}_{0}$ diterima dan $\mathrm{H}_{3}$ ditolak. Menurut Sujana (2010) komitmen organisasi tidak 
mampu bertindak sebagai variabel moderasi disebabkan oleh komitmen individu yang tumbuh terbatas pada pemenuhan kewajiban yang dibebankan kepadanya saja, di mana individu dalam organisasi akan berbuat sesuatu yang menjadi tanggung jawabnya saja. Dengan kata lain, komitmen hanya di wilayah kerjanya dan tidak tertarik untuk membantu sesuatu yang berada di luar tanggung jawabnya. Di samping itu, komitmen individu terhadap organisasi muncul berdasarkan pertimbangan cost benefit. Dengan menunjukkan kinerja yang baik, maka kompensasi yang akan diterima juga meningkat.

Hasil penelitian ini tidak sesuai dengan teori yang dinyatakan oleh Porter et., al (1978) yang menyatakan bahwa komitmen organisasi yang kuat dalam diri individu akan menyebabkan individu berusaha keras mencapai tujuan organisasi sesuai dengan tujuan dan kepentingan organisasi, serta akan memiliki pandangan positif dan berusaha berbuat terbaik demi kepentingan organisasi, sehingga perilaku disfungsional (senjangan anggaran) yang timbul pada saat proses penganggaran dapat dihindari. Hasil penelitian ini mendukung penelitian yang dilakukan oleh Venusita (2008), Kartika (2010), Sujana (2010), dan Rahmiati (2013) yang menyatakan komitmen organisasi tidak mampu memoderasi asimetri informasi dengan senjangan anggaran.

\section{SIMPULAN}

Berdasarkan hasil analisis dan pembahasan maka dapat ditarik simpulan yaitu asimetri informasi berpengaruh positif pada senjangan anggaran di Satuan Kerja Perangkat Daerah (SKPD) berupa Dinas pada Pemerintahan Kabupaten Tabanan. Kejelasan sasaran Anggaran memperlemah hubungan asimetri informasi pada 
senjangan anggaran di Satuan Kerja Perangkat Daerah (SKPD) berupa Dinas pada Pemerintahan Kabupaten Tabanan. Komitmen Organisasi tidak berpengaruh pada hubungan asimetri informasi pada senjangan anggaran di Satuan Kerja Perangkat Daerah (SKPD) berupa Dinas pada Pemerintahan Kabupaten Tabanan.

Saran yang dapat diberikan yaitu bagi pejabat atau pemimpin hendaknya mengawasi lebih lanjut dalam proses penyusunan anggaran yang akan dilakukan. Serta bagi peneliti selanjutnya dapat melakukan penelitian dengan menggolongkan komitmen organisasi menjadi dua kelompok, yaitu tinggi dan rendah sehingga dapat diketahui secara detail pengaruh komitmen organisasi dengan senjangan anggaran, serta memilih variabel yang lain yang mempengaruhi senjangan anggaran.

\section{REFERENSI}

Agusti, Restu. 2012. Pengaruh Partisipasi Penyusunan Anggaran Terhadap Kinerja Aparatur Pemerintah Daerah Dengan Dimoderasi Oleh Variabel Desentralisasi Dan Budaya Organisasi (Studi Kasus Pada Pemerintah Kabupaten Bengkalis). Jurnal Ekonomi, 20(3), pp: 1-15.

Aprila, Nila. 2012. The Effect Of Budgetary Participation, Asymetry Information, Budget Emphasis And Commitment Organization To Budgetary Slack At SKPD Governmental Of Bengkulu City. E-Jurnal of Economic Universitas Sriwijaya. pp. 617-628.

Citra Dewi, 2013. Pengaruh Penganggaran Partisipatif pada Senjangan Anggaran dengan Budgetary Control dan Komitmen Organisasi Sebagai Variabel Pemoderasi. E-Jurnal Akuntansi Universitas Udayana, 5(3), pp: 707-722.

Cook, John dan Toby Wall. 1980. New Work Attitute Measures of Trust, Organizations Commitment, and Personal Need Nonfullfillment. Journal of Accupational Psychology, pp: 39-52. 
Ni Made Kusuma Ayuni dan Ni Made Adi Erawati. Pengaruh ...

De Faria, Juliano Almeida dan Sônia Maria Gomes da Silva. 2013. The effects of information asymmetry on budget slack: An experimental research. African Journal of Business Management. 7(13), pp: 1086-1099.

Desmiyawati. 2009. Pengaruh Partisipasi Anggaran Terhadap Senjangan Anggaran dengan Komitmen Organisasi Sebagai Variabel Moderating. Jurnal Ekonomi Universitas Riau. 1(2), pp: 91-99.

Dunk, A.S. 1993, The Effect of Budget Emhpasis and Information Assymetry on Relation Between Budgetary Participation and Slack. The Accounting Review, 68(2), pp: 400-410.

Hui, $\mathrm{H}$ dan Islam. 2012. A Review of Literature on Contingency theory in Managerial Accounting. African Journal Of Bussines Management. Vol. 6 (5), pp. 5159-5164

Jensen, M. C dan Meckling, W.H. 1976. Theory of the Firm : Managerial Behavior, Agency Costs and Ownership Structure . Journal of Financial Economics, 3(4), pp. 305-360.

Kartika, Andi. 2010. Pengaruh Komitmen Organisasi dan Ketidakpastian Lingkungan dalam Hubungan Antara Partisipasi Anggaran dengan Senjangan Anggaran (Studi Empirik Pada Rumah Sakit Swasta di Kota Semarang). Jurnal Akuntansi, pp: 39-60.

Latif, Ria Angelina. 2013. Pengaruh Informasi Asimetri Terhadap Budgetary Slack Pada Pemerintah Daerah Bolaang Mongondow Utara. Jurnal Akuntansi Universitas Negeri Gorontalo.

Latuheru, Belianus Patria. 2005. Pengaruh Partisipasi Anggaran terhadap Senjangan Anggaran dengan komitmen Organisasi sebagai Variabel Moderating. Jurnal Akuntansi Universitas Kristen Indonesia MalukuAmbon. Vol. 7(2).

Lawrence, Paul dan Lorcsch Jay. 1967. Organization and environment. Harvard University USA.

Lau, C., dan Eggleton, I. 2003. The influence of information asymmetry and budget emphasis on the relationship between participation and slack. Accounting and Business Reserch,33(2), pp: 91-104. 
Locke, Edwin Latham. 1984. Goal Setting. A motivational technique that works. Prentice Hall. Inc Englewood, New Jersey.

Mahadewi, A. A. Sagung Sinta. 2014. Pengaruh Partisipasi Penganggaran Pada Senjangan Anggaran Dengan Asimetri Informasi Dan Komitmen Organisasi Sebagai Pemoderasi. E-Jurnal Akuntansi Universitas Udayana, 8(3), pp: 458-473.

Meyerd, J.P., Allen, N.J., Smith, C.A. 1993. Commitment to organizations and occupations: extension of a test of a three-component conceptualization. Journal of Applied Psychology, 78, pp: 538-551.

Modway, R., R. Steers, dan L. Porter. 1979. The Measurement of Organizational Commitment. Journal of Vacational Behavior, 14, pp: 224-235.

Nouri, H, dan R.J. Parker. 1996. The Effect of Organisational Commitment and Relation between Budgetary Participation and Budgetary Slack. Behavior Research in Accounting 8, pp: 74- 89.

Pello, Elizabeth Vyninca. 2014. Pengaruh Asimetri Informasi dan Locus Of Control pada Hubungan Antara Penganggaran Partisipatif dengan Senjangan Anggaran. E-Jurnal Akuntansi Universitas Udayana, 6(2), pp:287-305.

Pitasari, K.K.A., Sulindawati, N.L.G.E., dan Atmaja, A.T.A. 2014. Pengaruh Kejelasan Sasaran Anggaran dan Keadilan Prosedual terhadap Senjangan Anggaran (Budgetary Slack) pada SKPD berupa Dinas di Pemerintahan Kabupaten Klungkung. Universitas Pendidikan Ganesha.Jurnal Akuntansi, 2(1).

Putra, Deki. 2013. Pengaruh Akuntabilitas Publik Dan Kejelasan Sasaran Anggaran Terhadap Kinerja Manajerial Satuan Kerja Perangkat Daerah (Studi Empiris Pada Satuan Kerja Perangkat Daerah Kota Padang).Jurnal Akuntansi Universitas Negeri Padang, 1(1).

Putri, Gusti Ayu Made Cika. 2016. Pengaruh Kejelasan Sasaran Anggaran, Karakter Personal, dan Information Asymetry pada Senjangan Anggaran. E-Jurnal Akuntansi Universitas Udayana, 14(3), pp: 1555-1583 
Rahmiati, Elfi. 2013. Pengaruh Partisipasi Anggaran Terhadap Senjangan Anggaran Dengan Asimetri Informasi Dan Komitmen Organisasi Sebagai Pemoderasi. Jurnal Akuntansi.Universitas Negeri Malang, 1(2).

Roudhiah, Noor., Rozita amiruddin, dan Sofiah Md Auziar. 2014. Impact Of Organisational Factors On Budgetary Slack. Synergizing Knowledge on Management and Muamalah.

Rukmana, Paingga DB. 2013. Pengaruh Partisipasi Anggaran dan Asimetri Informasi Terhadap Timbulnya Budget Slack (Studi Empiris Pada Pemerintah Kota Padang). Jurnal Akuntansi Keuangan. 1(1).

Saad Saleh Al-Rwita. 2002. Budgetary slack: The Effects of Truth-Inducing Schemes on Slack and Performance. Economics and Administratiom Journal, 16 (2).

Stevens, Douglas. 2000. Determinants of Budgetary Slack in The Laboratory: An Investigation of Controls for Self-Interested Behavior. Syracouse University. 14.

Suartana, I Wayan. 2010. Akuntansi Keprilakuan. Yogyakarta: ANDI.

Sugiyono. 2014. Metode Penelitian Pendidikan Pendekatan Kuantitatif, Kualitatif Dan $R \& D$. Bandu

Suhartono, Ehrmann dan Mochammad Solichin. 2006. Pengaruh Kejelasan Sasaran Anggaran Terhadap Senjangan Anggaran Instansi Pemerintah Daerah Dengan Komitmen Organisasi Sebagai Pemoderasi. Simposium NasionalAkuntansi 9, pp: 1-20.

Sujana. 2010. Pengaruh Partisipasi Anggaran, Penekanan Anggaran, Komitmen Organisasi, dan Ketidakpastian Lingkungan Terhadap Budgetary Slack Pada hotel Berbintang Di Kota Denpasar. Jurnal Akuntansi. Fakultas Ekonomi Universitas Udayana. Vol:5 (2).

Venusita, Lintang. 2008. Partisipasi Anggaran dan Keterlibatan Kerja terhadap Senjangan Anggaran dengan Komitmen Organisasi sebagai Variabel Moderating.Jurnal Akuntansi Universitas Widya Kartika Surabaya. Vol:2(1). 
Wiener, Y. 1982. Commitment in Organization: A Normative View. Academy of Management Review 7, pp: 418-428.

Young, S.M. 1985. Participative Budgeting: The Effect of Risk Aversion and Assymetric Information on Budgetary Slack Journal of Accounting Research, 23, pp: 829-842.

Zurnali, Cut. 2010. Learning Organization, Competency, dan Customer Orientation : Knowledge Worker-Kerangka Riset Manajemen Sumber Daya Manusia Masa Depan. Bandung: Unpad Pres 